\title{
ANALISIS SOSIAL EKONOMI USAHA PERIKANAN JARING INSANG DI WADASLINTANG, JAWA TENGAH
}

\author{
Achmad Azizi"), Endi Setiadi Kartamihardja"), dan Didi Sadili")
}

\begin{abstract}
ABSTRAK
Pembangunan Waduk Wadaslintang mempunyai dampak terhadap perubahan struktur ekonomi masyarakat dari usaha pertanian ke usaha perikanan. Penelitian ini bertujuan untuk mendapatkan data dan informasi mengenai keragaan usaha perikanan jaring insang (gillnet) dan aspek usaha sosial ekonominya di Waduk Wadaslintang, Jawa Tengah. Penelitian ini dilakukan dengan metode survai. Hasil penelitian menunjukkan bahwa usia nelayan berkisar 19-60 tahun, pendidikan formal tamatan SD, dan pengalaman sebagai nelayan 1-7 tahun. Persentase nelayan yang pendapatan keluarganya mengandalkan dari perikanan $100 \%$ adalah $61,7 \%$, sedangkan yang kurang dari $50 \%$ adalah $11,7 \%$. Tingkat keuntungan yang diperoleh nelayan dalam usaha perikanan jaring insang adalah Rp 563.215/tahun. Jenis ikan hasil tangkapan yang paling disukai adalah ikan beong (Mystus nemurus) karena ikan beong mempunyai keunggulan tekstur daging dan rasa yang lebih gurih bila dibandingkan dengan ikan lainnya. Pemasaran ikan hasil tangkapan melalui dua saluran pemasaran yaitu: (1) dimulai dari nelayan ke pedagang pengumpul, pedagang perantara, pedagang besar, dan terakhir ke konsumen, dan ke (2) dari nelayan langsung ke konsumen.
\end{abstract}

ABSTRACT: Socio-economic analysis of gillinet in Wadaslintang Reservoir, Central Java. By: Achmad Azizi, Endi Setiadi Kartamihardja, and Didi Sadili

The establishment of Wadaslintang reservoir has affected the socio-economic structure of its society such as shifting of the job from cropping to fisheries. The objective of the study was to gather data and information on performance and socio-economics of gillnet fishery in Wadaslintang Reservoir, Central Java. A short survey of randomized samples was taken. The result of the study showed that the average age of the fishermen ranged between 19-60 years with 1 - 7 years of experience. Fishers can be categorized into full time (61-7\%), and part time (11,7\%) ones. The average income of the fishermen from gillnet operation was Rp 563,215 per year, equivalent to $968 \mathrm{kgs}$ of rice. Fish species mostly preferred by fishers as well as consumers was "beong" (Mystus nemurus). The market of the catch had two channels, i.e. (1) from fishermen to whole seller, broker, big seller, and consumer, and (2) from fishermen to consumer.

Keywords: $\quad$ socio-economic, gillnet, Reservoir Wadaslintang, marketing

\section{PENDAHULUAN}

Propinsi Jawa Tengah memiliki beberapa perairan waduk yang potensial untuk usaha perikanan, baik usaha perikanan tangkap maupun usaha budi daya ikan. Salah satu waduk yang terdapat di Kabupaten Wonosobo adalah Waduk Wadaslintang dengan luas permukaan air maksimal 1.400 ha, sedangkan luas minimal adalah 1.120 ha. Waduk ini mempunyai potensi bagi peningkatan kesejahteraan masyarakat terutama bagi mereka yang lahannya terkena pembangunan bendungan melalui pengembangan usaha perikanan (baik usaha penangkapan maupun usaha budi daya ikan).

Nelayan merupakan kelompok penduduk termiskin di Indonesia. Kemiskinan ini berhubungan dengan sifat-sifat intrinsik usaha, produk dan sumber daya, di samping itu juga masalah teknologi, kelembagaan, dan peraturan pemerintah. Usaha penangkapan ikan merupakan usaha yang bersifat penuh risiko dan musiman. Sifat-sifat ini kadang-kadang menjadikan usaha perikanan tangkap tidak menarik bagi pemilik modal sehinggga modal menjadi faktor yang langka. Selain itu ikan memiliki sifat yang mudah busuk dan harganya yang relatif murah.

Kinerja subsistem produksi perikanan perairan umum mempunyai sifat yang sangat spesifik bila dibandingkan dengan subsistem produksi perairan lainnya. Sumber daya perikanan, khususnya perikanan perairan umum bersifat common property yaitu dapat dimanfaatkan oleh penduduk/masyarakat sekitar perairan.

Ikan mempunyai kebiasaan bergerombol atau berpencar menurut pola dan besarnya variasi jenis

\footnotetext{
? Peneliti pada Pusat Riset Pengolahan Produk dan Sosial Ekonomi Kelautan dan Perikanan

- Peneliti pada Balai Penelitian Perikanan Air Tawar
} 
ikan, waktu, serta ruang, karena faktor alami yang sangat sukar dikontrol, seperti keadaan musim, tersedianya makanan alami, dan lingkungan habitat yang selalu berubah (luas pemukaan air, suhu, $\mathrm{pH}$, kekeruhan). Oleh karena itu produksi sumber daya ikan perairan umum sulit ditentukan secara pasti dan selalu berfluktuasi

Produksi ikan hasil tangkapan yang sulit ditentukan, menyebabkan pemanfaatan sumber daya ikan selalu berhadapan dengan risiko ketidakpastian yaitu pada suatu saat produksi ikan hasil tangkapan yang diharapkan dapat tercapai dan suatu saat terjadi sebaliknya. Masalah yang timbul dalam kegiatan usaha penangkapan ikan adalah bagaimana menghasilkan ikan di perairan umum yang layak dalam memenuhi skala usaha secara ekonomi maupun teknik.

Salah satu kegiatan perikanan yang berkembang di Waduk Wadaslintang adalah usaha penangkapan ikan dengan menggunakan jaring insang (gillnet). Alat tangkap ini bersifat pasif dan selektif, serta bisa dipakai sebagai alat penelitian untuk mengetahui populasi ikan di waduk dan danau (Golland, 1983)

Pada tahun 1994, jumlah nelayan yang berpotensi di Waduk Wadaslintang berjumlah 261 rumah tangga perikanan (RTP) (Diskan, 1996). Produksi perikanan di Waduk Wadaslintang diartikan sebagai jumlah ikan yang dihasilkan/ditangkap. Pertumbuhan perkembangan produksi perikanan ini sangat ditentukan oleh perubahan banyaknya jumlah hasil tangkapan. Sebagai sumber pertumbuhan baru diperlukan kajian dari berbagai faktor, yaitu faktor teknis (teknologi, alat tangkap yang digunakan, ketersediaan sarana dan prasarana yang menunjang usaha penangkapan), faktor ekonomi (harga ikan, struktur pasar, dan pola konsumsi masyarakat), faktor sosial (tingkat pendidikan, distribusi pendapatan nelayan, dan ketersediaan sumber daya manusia yang memiliki keahlian dan ketrampilan dalam memanfaatkan sumber daya perairan), dan faktor pemerintah (terutama mengenai kebijakan dalam membantu kelancaran usaha penangkapan ikan di perairan umum). Dengan penerapan pola pengelolaan perikanan yang rasional, usaha perikanan tangkap tersebut dapat memberikan kontribusi terhadap pendapatan masyarakat di sekitar waduk dan pendapatan daerah serta dapat memasok kebutuhan protein hewani khususnya dari ikan.

Penelitian ini bertujuan untuk mendapatkan data dan informasi mengenai keragaan usaha perikanan jaring insang dan aspek sosial ekonominya sebagai data dan informasi yang diperlukan bagi kebijakan pengelolaan perikanan di Waduk Wadaslintang.

\section{METODE PENELITIAN}

Penelitian ini dilakukan dengan menggunakan metode survai pada bulan Januari sampai bulan Maret 1997. Penentuan lokasi penelitian dilakukan berdasarkan perkembangan jumlah nelayan. Pengambilan responden nelayan dilakukan secara acak sederhana, sedangkan pengembalian sampel pedagang dilakukan dengan metode sensus yang dimaksudkan untuk mendapatkan data sebanyak mungkin dari jumlah pedagang yang ada. Jumlah responden seluruhnya sebanyak 57 orang, yang terdiri atas 47 responden nelayan dan 10 responden pedagang.

Data primer dikumpulkan dengan menggunakan daftar pertanyaan yang telah terpola melalui wawancara dan data sekunder dikumpulkan dari Dinas Perikanan Kabupaten Wonosobo dan instansi yang terkait.

Analisis data dilakukan secara deskriptif berdasarkan hasil tabulasi dari masukan dan keluaran untuk memberikan gambaran mengenai penangkapan ikan. Analisis mengenai masukan dan keluaran terhadap keuntungan usaha penangkapan dengan jaring insang, dapat memberikan gambaran mengenai keadaan sosial ekonomi usaha perikanan tangkap di Waduk Wadaslintang. Efisiensi usaha dapat diketahui dari berbagai tingkat keuntungan usaha yang merupakan pendapatan bersih (Weston \& Brihman dalam Hadi, 1988; Soekartawi et al., 1986). Efisiensi usaha dilihat dari tiga segi, yaitu, (1) hubungan dengan hasil penjualan (nilai produksi), (2) hubungannya dengan aset yang ditanam (investasi) yaitu total asset turn over dan (3) efisiensi keseluruhan yaitu earning power. Ketiga kaidah tersebut dapat dirumuskan sebagai berikut:

$$
\text { MarjinKeuntungan }(\mathrm{MK})=\frac{\sigma}{\mathrm{TR}}
$$

dengan:

$\sigma=$ keuntungan

$\mathrm{TR}=$ pendapa $\tan$ kotor

$$
\text { TATO }=\frac{T R}{T A}
$$

TATO $=$ Total ase t turn over

$\mathrm{TA}=$ Total aset

$$
\text { Earning Power }=\text { MK } \times \text { TATO }
$$

dengan:

$\mathrm{MK}=$ Margin keuntungan 


\section{HASIL DAN BAHASAN}

\section{Keadaan Umum Wilayah}

Waduk Wadaslintang terletak pada ketinggian 453 $m$ dari permukaan laut. Wadaslintang berada di antara Kabupaten Wonosobo dengan Kabupaten Kebumen dan merupakan jalan pintas untuk menuju Kebumen.

Perekonomian masyarakat Wadaslintang antara lain dicirikan sebagai penghasil produk pertanian dan industri rumah tangga seperti pembuatan gula kelapa. Produk hasil pertanian lebih banyak dipasarkan di wilayah lokal (Wadaslintang), hal ini dikarenakan pedagang perantara sudah mempunyai ikatan secara informasi.

\section{Aspek Sosial Nelayan}

Karakteristik masyarakat pedesaan di sekitar Waduk Wadaslintang termasuk daerah yang tergolong miskin meskipun keadaan jalan menuju Wadaslintang sudah baik dan merupakan jalur perekonomian masyarakat setempat. Hal ini terlihat dari tingkat pendapatan penduduk/petani pedesaan perkapita yang rata-rata sebesar $320 \mathrm{~kg}$ beras per tahun yang menurut Sayogya (1980) sama dengan besarnya pengeluaran untuk kebutuhan rumah tangga.

Sebagian penduduk di sekitar Waduk Wadaslintang mengusahakan lahannya untuk usaha pertanian. Kegiatan pertanian yang dilakukan oleh sebagian nelayan adalah bertanam jagung, palawija, ketela pohon, ubi jalar, dan tanaman pangan lainnya. Dalam penanaman ketela pohon menghasilkan satu kali dalam setahun, sedangkan tanaman jagung dan ubi jalar menghasilkan dua kali dalam setahun.

Usia merupakan hal yang sangat penting dalam melakukan aktivitas, karena usia dapat berpengaruh terhadap pengambilan keputusan. Usia rata-rata nelayan di Waduk Wadaslintang adalah 37 tahun dengan kisaran usia antara 19-60 tahun. Usia nelayan tersebut (37 tahun) merupakan usia yang produktif dan cepat dalam menyerap teknologi.

Salah satu ukuran kualitas tenaga manusia adalah tingkat pendidikan dan keterampilan yang dimiliki. Sedangkan Pasaribu \& Simanjuntak (1982) mengatakan bahwa pendidikan adalah suatu proses di mana manusia membina perkembangan manusia lainnya secara sadar dan berencana. Dengan demikian pendidikan dapat meningkatkan pengetahuan seseorang terhadap teknologi yang sedang berkembang maupun yang akan berkembang seperti alat tangkap jaring insang dari yang sudah ada ke yang lebih baik. Pendidikan yang dicapai oleh nelayan pada umumnya hanya tamatan sekolah dasar
$(87,8 \%)$ dan hanya satu dua orang saja tamat SLTP, namun demikian di antara mereka tidak ada yang buta aksara. Pendidikan nonformal yang penah diikuti oleh beberapa nelayan adalah kursus mengenai teknik penangkapan dan budi daya ikan di keramba jaring apung (KJA) yang diselenggarakan oleh Dinas Perikanan Wonosobo. Hasil kursus yang sudah dapat diadopsi adalah kegiatan penangkapan ikan dengan jaring insang. Dilihat dari segi pendidikan tersebut terlihat bahwa nelayan Waduk Wadaslintang termasuk nelayan berpendidikan rendah. Namun demikian, nelayan tersebut mempunyai pengalaman menangkap ikan yang memadai yaitu rata-rata 4 tahun dengan kisaran antara 1-7 tahun. Pengalaman nelayan yang relatif lama tersebut menjadikan mereka cukup terampil dalam menangkap ikan, menentukan lokasi dan pembuatan alat tangkap. Hal ini terbukti dari pengetahuan mereka tentang waktu yang tepat untuk melakukan penangkapan, jenis alat tangkap yang digunakan, lokasi penangkapan, dan jumlah tenaga yang dibutuhkan.

Keterampilan lain yang dimiliki nelayan adalah dalam pengaturan pembagian kerja di antara kelompok dengan tenaga kerja keluarga untuk mencapai keuntungan yang maksimal dari usaha penangkapan. Menurut Manurung (1984), pendidikan dan keterampilan ini akan berpengaruh terhadap cara berfikir dan pada gilirannya akan berpengaruh terhadap pengembalian keputusan dan pengaturan ekonomi rumah tangga.

Perkembangan jumlah nelayan di Waduk Wadaslintang menunjukkan pertumbuhan yang sedang. Dalam periode 1987 sampai dengan 1997, jumlah nelayan bertambah dari 70 RTP menjadi 261 RTP (Diskan, 1996) atau meningkat $72,8 \%$ dalam kurun waktu 7 tahun atau rata-rata $10,4 \%$ per tahun. Pertumbuhan RTP ini antara lain disebabkan terjadinya peralihan mata pencaharian dari pertanian ke perikanan, khususnya perikanan tangkap sebagai perikanan pokok

Angka-angka pertumbuhan nelayan tersebut memberikan petunjuk bahwa sektor perikanan tangkap di Waduk Wadaslintang dapat membuka kesempatan kerja. Cepatnya pertambahan nelayan menunjukkan kecenderungan masuknya angkatan kerja baru ke sektor perikanan dalam jumlah cukup besar. Namun diketahui bahwa sektor perikanan tangkap di perairan umum adalah sektor perikanan yang tradisional dan termasuk lapangan kerja kasar dengan tingkat pendapatan yang rendah sehingga perikanan tangkap bukan merupakan lapangan kerja idaman

Persentase jumlah nelayan yang penghasilannya tergantung kepada sumber pendapatan dari hasil perikanan tangkap disajikan pada Tabel 1 
Tabel 1. Persentase nelayan terhadap pendapatan kerja, tahun 1997

Table 1. Distribusi of fishermen by percentage to total family income generated from fishing 1997

\begin{tabular}{cc}
\hline $\begin{array}{c}\text { Persentase jumlah nelayan } \\
\text { Percentage of fishermen }\end{array}$ & $\begin{array}{c}\text { Persentase pembagian jumlah nelayan terhadap total pendapatan } \\
\text { Percentage of distribution of fishermen to total family income }\end{array}$ \\
\hline 63,8 & 100 \\
21,2 & 75 \\
10,7 & 50 \\
4,3 & 25 \\
0 & 0 \\
\hline
\end{tabular}

Dari Tabel 1 di atas menunjukkan bahwa jumlah nelayan yang pendapatan keluarga $100 \%$ tergantung dari hasil perikanan tangkap adalah $63,8 \%$, sedangkan persentase nelayan yang kontribusi pendapatannya dari hasil penangkapan $75 \%$ hanya $21,2 \%$ dan nelayan yang mengandalkan $50 \%$ dari perikanan tangkap untuk kebutuhan rumah tangga adalah 10,7\% dan yang hanya $25 \%$ adalah $4,3 \%$ untuk kebutuhan keluarga. Pendapatan yang rendah dan tidak memadai untuk kebutuhan pendapatan keluarga, menyebabkan mereka terpaksa harus memperoleh tambahan pendapatan lain di luar sektor perikanan (Mubyarto, 1984). Kegiatan nelayan di luar penangkapan ikan adalah berdagang dan bertani.

Rata-rata jumlah tanggungan keluarga yang menjadi tanggungan kepala keluarga nelayan adalah 5,6 orang dengan kisaran 4-9 orang. Sedangkan yang menjadi tanggungan keluarga di sini adalah jumlah anak atau famili yang masih menjadi tanggung jawab keluarga dalam kebutuhan sehari-harinya.

Jumlah tanggungan keluarga nelayan di Waduk Wadaslintang cukup tinggi bila dibandingkan dengan program keluarga berencana. Jumlah keluarga yang akan berpengaruh terhadap tingkat kesejahteraan keluarga.

\section{Karakteristik Alat Tangkap Jaring Insang}

Kegiatan perikanan yang telah berkembang di Waduk Wadaslintang adalah usaha penangkapan ikan dengan jaring insang dan pancing teger. Usaha perikanan dengan alat tangkap jaring insang merupakan usaha penangkapan yang dominan yaitu sekitar 93\%. Pada dasarnya jaring insang merupakan alat tangkap yang pasif dan selektif, di mana jenis dan ukuran ikan yang tertangkap di antaranya tergantung pada ukuran mata jaring yang digunakan (Hamley, 1980).

Jaring insang tersebut dari nylon yang transparan, bagian atas jaring diberi pelampung dari karet sendal jepit dan dibawahnya diberi pemberat agar jaring tersebut bisa terbentang dengan sempurna. Besarnya mata jaring yang digunakan oleh nelayan ditentukan oleh Dinas Perikanan Kabupaten Wonosobo yaitu tidak boleh lebih kecil dari 2 inci $(5 \mathrm{~cm})$. Hal ini dimaksudkan agar ikan kecil tidak tertangkap sehingga kelestarian sumber daya ikannya akan terjamin.

Jaring insang dioperasikan dengan jalan membentangkannya pada kedalaman $1 \mathrm{~m}$ di bawah permukaan air. Waktu yang dibutuhkan dalam satu trip penangkapan adalah 12 jam. Dalam pengoperasian jaring insang ini digunakan perahu dayung dan hanya dibutuhkan sebanyak satu orang tenaga kerja. Jaring insang dioperasikan sepanjang tahun (tidak tergantung pada musim), meskipun demikian musim ikan yang tidak menentu mengakibatkan hasil tangkapan dari waktu ke waktu tidak dapat diduga dengan tepat.

Kegiatan penangkapan dengan jaring insang di Waduk Wadaslintang pada umumnya dapat dilakukan setiap hari dan tidak mengenal musim. Namun demikian pada hari Jumat para nelayan tidak melakukan kegiatan penangkapan, sehingga dalam satu minggu hanya dilakukan sebanyak 6 hari. Dalam setahun ratarata nelayan melakukan kegiatan penangkapan sebanyak 280 hari dengan kisaran $270-300$ hari. Jumlah hari operasional penangkapan ikan di Waduk Wadaslintang lebih sedikit dibanding Waduk Kedungombo yang rata-rata dalam satu tahun melakukan kegiatan penangkapan selama 312 hari (Kartamihardja et al., 1992). Jumlah nelayan yang beroperasi di Waduk Wadaslintang setiap harinya berkisar antara 166-241 orang. Jumlah dan jenis alat tangkap dapat dilihat pada Tabel 2. Dari Tabel tersebut dapat dilihat bahwa jenis alat tangkap yang dimiliki oleh nelayan adalah jaring insang ( gillnet) yaitu sebesar $80,4 \%$.

\section{Musim dan Hasil Tangkapan}

Penangkapan dengan menggunakan jaring insang berlangsung sepanjang tahun. Hasil tangkapan tertinggi (puncaknya) terjadi pada musim penghujan yaitu antara bulan September sampai bulan Januari. Hasil tangkapan sedang terjadi antara bulan Februari sampai bulan April dan hasil tangkapan terendah (musim paceklik) terjadi pada bulan Mei sampai Agustus. 
Tabel 2. Persentase jenis alat tangkap yang digunakan di Waduk Wadaslintang, tahun 1997

Table 2. Number of fishing gear in Wadaslintang Reservoir, 1997

\begin{tabular}{cc}
\hline Jenis alat tangkap & $\begin{array}{c}\text { Persentase jumlah } \\
\text { Pype of gear }(\mathbf{N}=\mathbf{4 7})\end{array}$ \\
\hline Jaring insang/Gillnet & 80,4 \\
Pancing/Rawe & 19,6 \\
(Hook/mini longline) & \\
\hline
\end{tabular}

Jumlah hasil tangkapan rata-rata pada musim puncak/ikan adalah $25 \mathrm{~kg}$ per hari dengan kisaran 20-40 kg per hari. Pada musim sedang $12 \mathrm{~kg}$ per hari dengan kisaran 9-15 kg per hari, sedangkan pada musim paceklik produksi hasil tangkapan adalah 4 $\mathrm{kg}$ per hari dengan kisaran hasil tangkapan 3-6 kg per hari. Ikan hasil tangkapan nelayan dibeli oleh pedagang pengumpul dengan harga Rp2.000/kg.

\section{Jumlah Pemilikan Alat Tangkap}

Pemilikan alat tangkap jaring insang sangat bervariasi, tergantung dari modal yang dimiliki nelayan. Jumlah pemilikan alat tangkap ini akan berpengaruh terhadap besarnya hasil tangkapan. Jumlah jaring yang dimiliki nelayan Waduk Wadaslintang dapat dilihat pada Tabel 3.

Dari Tabel di atas terlihat bahwa sebagian besar nelayan $(44,7 \%)$ hanya memiliki jaring insang antara membeli alat tangkap dan biaya pembayaran iuran izin usaha penangkapan. Pertemuan anggota kelompok nelayan ini biasanya dilakukan pada tanggal 10 setiap bulannya dan telah dimulai sejak tahun 1992.

\section{Jenis Ikan yang Tertangkap dan Preferensi Masyarakat}

Di Waduk Wadaslintang terdapat 14 jenis ikan (Kartamihardja, 1992). Jenis ikan yang dominan tertangkap dengan jaring adalah ikan tawes (Barbodes gonionotus), beong (Mystus nemurus), bader (Barbodes bramoides), palung (Hampala macrolepidota), katuk (Channa striata), nila (Oreochromis niloticus), nilem (Osteochilus hasselti), dan mata merah (Puntius orphroides). Ukuran ikan yang tertangkap tergantung dari ukuran mata jaring yang digunakan. Ukuran mata jaring yang digunakan dalam penangkapan adalah 1,5 inci; 2 inci; 3 inci;

Tabel 3. Jumlah alat tangkap jaring insang yang dimiliki nelayan di Waduk Wadaslintang

Table 3. Number of gillnet owned by fishermen in Wadaslintang Reservoir

\begin{tabular}{cc}
\hline $\begin{array}{c}\text { Persentase jumlah nelayan } \\
\text { Percentage of fishermen }\end{array}$ & $\begin{array}{c}\text { Jumlah gillnet yang dimiliki } \\
\text { Number of gillnet owned }\end{array}$ \\
\hline 44.7 & $2-3$ \\
34 & $4-5$ \\
17 & $6-7$ \\
4.3 & $>8$ \\
\hline
\end{tabular}

2-3 bar (piece), 34,0\% nelayan memiliki jaring insang 4-5 bar, dan jumlah nelayan yang memiliki jaring insang lebih dari 6 bar hanya $17,0 \%$. Dilihat dari pemilikan jaring insang yang relatif kecil yaitu antara $2-5$ bar (piece) hanya mencapai $78,7 \%$; ini menggambarkan bahwa nelayan Wadaslintang relatif masih kekurangan modal untuk pembelian alat tangkap.

Organisasi kelembagaan yang dapat menunjang kegiatan perikanan tangkap di Waduk Wadaslintang adalah kelompok nelayan, di mana fungsi dari kelompok tersebut adalah membina para nelayan dalam pengelolaan sumber daya perairan secara lestari. Di samping itu, kelompok nelayan melakukan simpan pinjam yang tujuannya untuk memudahkan nelayan dalam menghimpun modal kembali untuk dan 3,5 inci. Jenis ikan yang ditangkap pada umumnya merupakan jenis ikan yang mempunyai nilai ekonomis penting.

Hasil wawancara dengan nelayan dan konsumen akhir di sekitar Waduk Wadaslintang menunjukkan bahwa $70 \%$ nelayan dan konsumen akhir lebih menyukai ikan beong dengan alasan dagingnya lebih tebal, rasanya lebih gurih dan enak bila dibandingkan dengan ikan lainnya seperti ikan tawes, palung, dan wader.

\section{Investasi, Biaya Produksi, dan Pendapatan Usaha}

Biaya yang digunakan dalam usaha penangkapan dengan jaring insang terdiri atas biaya tetap dan biaya 
tidak tetap. Biaya tetap terdiri atas penyusutan alat tangkap, penyusutan perahu, dan biaya SIUP, sedangkan biaya tidak tetap terdiri atas bekal, perbaikan alat tangkap, dan perbaikan perahu. Nilai investasi, biaya tidak tetap, dan keuntungan dari hasil analisis usaha penangkapan ikan dengan jaring insang tertera pada Tabel 4 bahwa suatu daerah perkotaan termasuk miskin jika pendapatannya rata-rata setara dengan $480 \mathrm{~kg}$ beras perkapita per tahun. Dengan demikian, nelayan Waduk Wadaslintang termasuk kategori kelompok masyarakat pertanian dengan tingkat pendapatan relatif cukup baik. Oleh karena itu, jika standar pendapatan tersebut dipakai maka untuk mencapai

Tabel 4. Biaya dan keuntungan perikanan tangkap di Waduk Wadaslintang

Table 4. Cost and profit of gillnet fishery in Wadaslintang Reservoir, 1997

\begin{tabular}{lr}
\hline \multicolumn{1}{c}{ Item } & Nilai/Value (Rp.) \\
\hline Investasi//nvestment: & \\
Kapal/Boat & 125,000 \\
Alat tangkap/Gear & 450,000 \\
\hline Biaya Tetap/Fixed Cost: & \\
Penyusutan alat/Gear depreciation & 450,000 \\
Penyusutan kapal/Boat depreciation & 30,000 \\
ljin usaha/License (SIUP) & 3,000 \\
\hline Biaya Tidak Tetap/Variable Cost: & \\
Konsumsi/Consumption & 350,000 \\
Pemeliharaan alat/Gear maintenance & 15,000 \\
\hline Pemeliharaan kapal/Boat maintenance & 15,000 \\
\hline Jumlah/Total Cost & 863,000 \\
\hline Pendapatan/Revenue 900 kg x Rp 2,000,- & $1,800,000$ \\
\hline Keuntungan/Profit & 937,000 \\
\hline
\end{tabular}

Dari Tabel 4 tergambar bahwa kegiatan usaha penangkapan ikan di Waduk Wadaslintang dapat memberikan keuntungan sebesar Rp 937.000 per tahun yang menunjukkan bahwa nelayan tersebut miskin. Tingkat pendapatan tersebut menjadi tolok ukur kesejahteraan nelayan dalam garis kemiskinan. Bila nilai pendapatan tersebut dikonversikan ke dalam harga beras, maka penghasilan rata-ratanya adalah tingkat pendapatan tersebut, nelayan harus melakukan kegiatan usaha tambahan seperti pertanian, perkebunan, peternakan, atau budi daya ikan.

Dari data investasi, total biaya, penerimaan, dan keuntungan (Tabel 4) dapat dihitung efisiensi usaha perikanan tangkap dengan jaring insang, seperti tertera pada Tabel 5.

Tabel 5. Efisiensi dan keuntungan pengakapan ikan dengan jaring insang di Waduk Wadaslintang Table 5. Profit and efficiency of gillnet fishery in Wadaslintang Reservoir, 1997

\begin{tabular}{lr}
\hline \multicolumn{1}{c}{ Item } & \multicolumn{1}{c}{ Value } \\
\hline Investasi/Investment: & 575,000 \\
Biaya total/Total cost & 863,000 \\
Penerimaan/Revenue & $1,800,000$ \\
Keuntungan/Profit & 937,000 \\
\hline Tingkat efisiensi/Level of efficiency: & \\
Marjin keuntungan/Profit margin & $52.06 \%$ \\
Total asset tum over & 3.13 times \\
Eaming power & $162.96 \%$ \\
\hline
\end{tabular}

$960 \mathrm{~kg}$ beras per tahun (harga beras Rp 600). Nilai pendapatan ini ternyata berada di atas angka garis kemiskinan yang dikemukakan oleh Sayogya (1980)
Dari Tabel 5 diketahui bahwa bila efisiensi usaha dilihat dari segi hubungan dengan nilai produksi yaitu margin keuntungan sebesar $52,06 \%$, di mana setiap 
hasil penjualan Rp100 akan mendapatkan keuntungan sebesar Rp 52,06 maka efisiensi usaha dilihat dari hubungan investasi yang ditanam yaitu total asset turn over adalah sebesar 3,13 kali. Sedangkan bila dilihat dari segi efisiensi usaha secara keseluruhan yaitu earning power adalah sebesar $162,96 \%$. Ini memperlihatkan bahwa setiap Rp100,- modal yang ditanam akan menghasilkan keuntungan sebesar Rp162,96.

Bila dilihat dari segi pendapatan nelayan perikanan tangkap, nelayan jaring insang bisa dipandang sebagai investor, pekerja, pelaksana fungsi manajemen, diharapkan akan mendapatkan keuntungan lebih besar dari usaha perikanan tangkap.

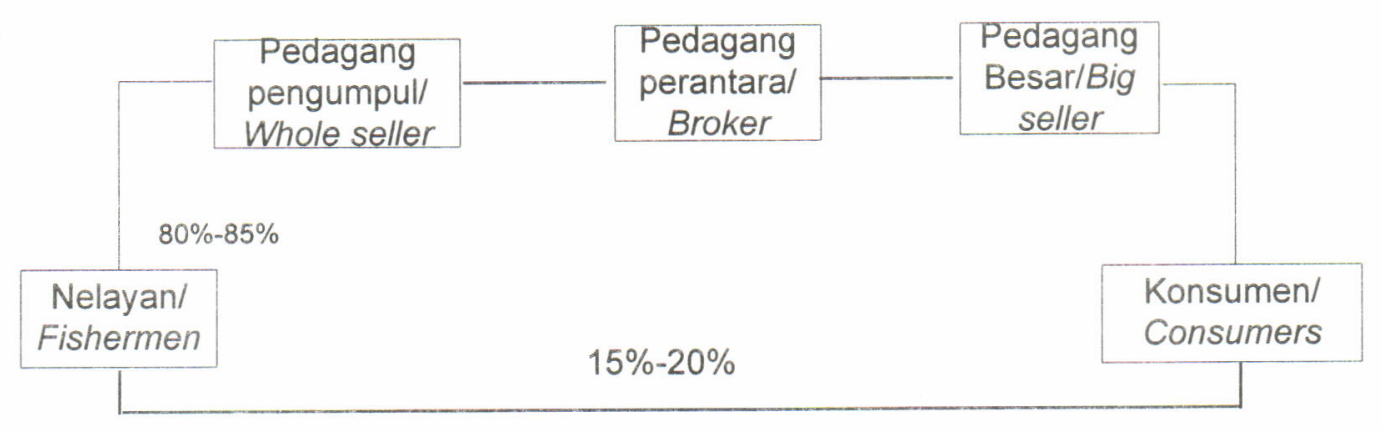

Gambar 1. Saluran pemasaran ikan hasil tangkapan di Waduk Wadaslintang, 1997

Figure 1. Marketing channel of fish cought by fishermen in Wadaslintang Reservoir, 1997

\section{PEMASARAN}

Lembaga pemasaran adalah badan-badan atau lembaga yang melakukan kegiatan atau fungsi pemasaran, seperti produsen, pedagang, dan lembaga pemberi jasa. Perseorangan atau suatu badan hukum yang berusaha dalam bidang pemasaran, dikategorikan sebagai pedagang perantara atau pedagang pengumpul. Menurut Abott \& Mahekam (1972), kumpulan dari berbagai pedagang perantara yang satu sama lainnya bertugas mendistribusikan barang sampai ke konsumen akhir disebut sebagai saluran pemasaran. Sedangkan menurut Southwarth (1971), pemasaran hasil pertanian khususnya produksi perikanan meliputi banyak fungsi yang dilaksanakan oleh lembaga pemasaran melalui bermacam-macam saluran, karena pemasaran merupakan salah satu bangunan (building blocks) dalam rangka sistem pemasaran secara keseluruhan. Yang termasuk dalam lembaga pemasaran antara lain adalah produsen dan pedagang. Golongan produsen adalah mereka yang tugas utamanya hanya menghasilkan barang, sedangkan golongan pedagang adalah mereka yang tugasnya menyalurkan hasil produksi dari nelayan.

Kegiatan pemasaran ikan hasil tangkapan di Waduk Wadaslintang sebagian kecil dilakukan oleh nelayan yang merangkap sebagai pedagang pengumpul dan pengecer ikan yang dijual baik berasal dari hasil tangkapannya sendiri maupun sesama rekannya. Kegiatan ini dilakukan setiap hari oleh nelayan tersebut untuk memenuhi permintaan masyarakat di sekitarnya.

Saluran pemasaran ikan hasil tangkapan dari Waduk Wadaslintang mempunyai dua saluran (Gambar 1). Pada umumnya saluran pemasaran yang berlaku adalah saluran pemasaran yang pertama yaitu mulai dari nelayan ke pedagang pengumpul, pedagang perantara, pedagang besar yang ada di luar wilayah Wadaslintang sampai ke konsumen akhir Sedangkan penjualan hasil tangkapan dari nelayan 
pemasaran ikan hasil tangkapan adalah Kabupaten Wonosobo dan Kebumen.

\section{KESIMPULAN}

Dari hasil penelitian ini dapat disimpulkan sebagai berikut:

1. Usaha perikanan jaring insang di Waduk Wadaslintang dilakukan oleh nelayan usia produktif dengan tingkat pendidikan formal tamatan SD, dan pengalaman rata-rata 4 tahun. Pada umumnya usaha perikanan ini merupakan pekerjaan utama dengan rata-rata pendapatan Rp563.125,- per tahun.

2. Sistem pemasaran ikan hasil tangkapan mempunyai dua saluran pemasaran yaitu (1) mulai dari nelayan kepada pedagang pengumpul, pedagang perantara, pedagang besar sampai konsumen akhir, dan (2) dari nelayan langsung ke konsumen akhir.

\section{DAFTAR PUSTAKA}

Abbot dan Mahekam, 1972. Agriculture Economic and in the Tropic, Longman, London. $497 \mathrm{pp}$.

Dinas Perikanan, 1996. Laporan Statistik Perikanan Kabupaten Wonosobo. Dinas Perikanan Kabupaten Tk. II Wonosobo, Jawa Tengah. 65pp

Golland, J.A, 1983. Fish stock assesment a manual of basic methods, FAO, Willey Seran. Food and Agriculture 1:223

Hamley, 1980. Riview of gillnet selectivity. J. Fish. Board. Canada 32 (2): 1943-1969.
Hadi, P.U., 1988. Analisis efisiensi usaha peternakan sapi perah di Jawa Barat. Prosiding Patanas, Perubahan Ekonomi Pedesaan Menuju Struktur Ekonomi Berimbang, Pusat Penelitian Sosial Ekonomi Pertanian. p.147-159.

Kartamihardja, E.S., M.F. Sukadi, dan Sutomo, 1992. Pengkajian sumberdaya perikanan untuk optimasi produksi ikan di Waduk Kedungombo. Prosiding Lokakarya Penelitian Komoditas dan Studi Kasus. Kerjasama Badan Litbang Pertanian dengan Perguruan Tinggi. Departemen Pendidikan dan Kebudayaan, Vol. 1: 23-39.

Kartamihardja, E.S., 1992. Beberapa aspek biolimnologi dan pengolahan perikanan di Wadaslintang, Wonosobo, Jawa Tengah. Bull. Penel. Perik. Darat. Vol. 11(1): 1-11.

Manurung, V.T., 1984. Nelayan kecil di Jawa, Kriteria dan Pembinaan. Jurnal Litbang Pertanian 3(2): 24-29.

Mubyarto, 1984. Pengantar Ekonomi Pertanian, LP3ES Jakarta. $86 \mathrm{pp}$.

Pasaribu, H. dan B. Simanjuntak, 1982. Proses Belajar Mengajar. Tarsito. Bandung. 54 pp.

Southwath, H.M., 1971. Agriculture Marketing of Developing Countries A/D/C. $389 \mathrm{pp}$.

Sayogya, 1980. Penelitian tingkat pendapatan dan tingkat hidup nelayan. Makalah Workshop Sosial Ekonomi Perikanan Indonesia. Cisarua, 2-4 November 1982. Puslitbang Perikanan, Badan Litbang Pertanian, Deptan, Jakarta, p. 277-279.

Soekartawi, A. Soeharjo, J.L. Dillon, dan J.B. Hardeker, 1986. IImu Usaha Tani dan Penelitian untuk Pengembangan Petani Kecil. Penerbit Universitas Indonesia, Jakarta. $162 \mathrm{pp}$. 